Article

\title{
Abandonment or Regeneration and Re-Use? Factors Affecting the Usage of Farm Premises in Different Social Spaces of the Rural
}

\author{
Josef Navrátil *®D, Tomáš Krejčí, Stanislav Martinát@ ${ }^{\circledR}$ Kamil Pícha@, Petr Klusáček, \\ Jaroslav Škrabal and Robert Osman \\ Department of Environmental Geography, Institute of Geonics of the Czech Academy of Sciences, Drobného 28, \\ 60200 Brno, Czech Republic; tomas.krejci@ugn.cas.cz (T.K.); stanislav.martinat@ugn.cas.cz (S.M.); \\ kamil.picha@centrum.cz (K.P.); petr.klusacek@ugn.cas.cz (P.K.); skrabal@opf.slu.cz (J.Š.); \\ robert.osman@ugn.cas.cz (R.O.) \\ * Correspondence: josefnav@gmail.com
}

Received: 10 October 2020; Accepted: 31 October 2020; Published: 3 November 2020

check for updates

\begin{abstract}
Nearly every village in Central and Eastern European countries with heavily collectivized agriculture has its collective farm premises that encompass substantial parts of the village area, were built in the sixties, and now are unable to be used in former ways. The aim of the paper is to identify indicators that are relevant for spatial disparities in the utilization of agricultural premises thirty years after the fall of the Iron Curtain. The location and its area of all pre-1989 rural farm premises within two NUTS 3 regions of the Czech Republic with its current uses were identified, and differences in present uses were tested against agri-natural and socio-economic characteristics (of the municipalities where rural farm premises are located) obtained from national databases. From a global point of view, socio-economic characteristics of municipalities were found to be exceedingly more important than agri-natural-thus, changing of uses is rather dependent on socio-economic context than on geographical preconditions of agriculture. Surprisingly, agricultural use or re-use can be primarily found in municipalities not suitable for intensive agriculture located in the fodder crops and potatoes areas of agricultural production with the highest shares of permanent grassland on agricultural land. On the other hand, areas with the best preconditions for agriculture tend to re-use former farm premises for non-agricultural production.
\end{abstract}

Keywords: space recycling; brownfields; agricultural change; central Europe

\section{Introduction}

It is traditionally assumed that social structures of rural areas are conservative "by definition" and are persistent to precipitous changes [1]. However, rural areas of Central and Eastern European countries (CEE) underwent several substantial multi-level transitions during the 20th century [2-7], making them unique and surprisingly still an under-researched laboratory for rural studies. Moreover, the continuous development of agri-systems induced by technical progress [8], the development of the society as a whole, and severe changes in land ownership overwhelmingly changed the life of people in villages of CEE countries [9,10].

Even though it has been three decades since the last transformation of the countryside after the collapse of the communist system in CEE countries [4], the legacy of the era of communism is still to be carried [11]. The depth of the collectivization of agriculture (and with it, the total changes of life in the rural countries of the Eastern Bloc) will be evident when we consider that this transformation lasts almost the same time as the era of collectivized agriculture $[12,13]$. 
A significant specificity of the countryside of CEE countries is represented by agricultural premises that were built during the era of collectivized agriculture in the socialist period [14]. They were created by large agricultural "enterprises" such as collective farms (cooperative sector) and state farms (state sector) that were established after communists took power in 1948 [2]. Nearly every village, except Poland and former Yugoslavia [15], has its collective farm premises that encompass substantial parts of the village area, were built in the sixties, and now are unable to be used in former ways [16].

The changes that started thirty years ago after the fall of the Iron Curtain were not similar in all agricultural areas of the Czech Republic [17]. Natural and social and economic conditions for agriculture were also not the same [4]. Thus, the agricultural transition was regionally specific, and various developmental trajectories occurred [14,18]. These changes can also be manifested in the occurrence of abandoned agricultural premises [19]. On the contrary, the changes in the utilization of agricultural premises reflect various conditions in individual regions. We already know from previous studies conducted on small-scale spatial patterns that such links can exist $[16,20,21]$. Analyses from other than rural environs already proved-made on military training areas [22], industrial zones [23,24], or in residential urban areas $[25,26]$ - that such pattern surely exists. Therefore, it is quite surprising that the complex perspective on the transition in the usage of agricultural premises is still lacking, although it is obvious that this research problem is truly important in the CEE context [11]. Moreover, brownfields after agriculture traditionally belong to the most frequent sites that have been abandoned, neglected, and contaminated during the transition period [27].

The integration of knowledge on the transition of the utilization of agricultural premises into wider transition theory was our motivation to work on this research. The paper aims to identify indicators that are relevant for spatial disparities in the utilization of agricultural premises thirty years after the fall of the Iron Curtain.

\section{Conceptual Background}

After World War II and based on the president's Beneš decrees, the expulsion of Germans started and confiscation of their properties took place [28] in former Czechoslovakia. These processes completely changed the Czech borderland, especially the broad regions along the Austrian, Bavarian, and Saxonian borders [29]. After 1948, the communist regime took power, which was quickly followed by the collectivization and nationalization of agricultural land and properties [30]. This process was visible in almost all countries behind the Iron Curtain, but its results most affected Czechoslovakia among all CEE countries. Almost $94 \%$ of agricultural land was collectivized here by the end of the 1950s [15].

The main endeavor of the communist agricultural policy was to adopt the "one village, one farm" model known from the Soviet Union. Collectivization made possible building up wide agricultural premises that served the whole collective farm-e.g., cowsheds, piggeries, operational buildings [16]. These new premises changed the design of Czech villages and thus created new, sometimes artificial and economically not viable, but always influential, centers of rural life. However, even in the conditions of the planned economy, this model was difficult to sustain. From the 1970s, cooperative farms were merged by the interventions of the central government to make larger and supposedly more prosperous organizational agricultural units [31].

For forty years, collective farms were the central points of rural life in Czechoslovakia, interconnecting work on the farm with social and cultural life in every single village [31]. Privately owned farms were violently taken over. Only a couple of small-scale farms survived this era in the mountains. Collectivized villages were presented as an ideal form of communist rural space [32], where entirely new social relations occurred. However, the new collective farms were not competitive as they were applying obsolete methods of production and management [31]. After 1990, when the transition started, economic shock after the opening of the planned economy to free markets was strengthened by the privatization of properties, especially by the restitution that brought massive changes to both the extent and structure of agricultural production [17]. It is not a big surprise that the change in the utilization of oversized 
agricultural premises was an integral part of this process, and numerous abandoned agricultural brownfields rapidly occurred on the real estate market (Figures 1 and 2).

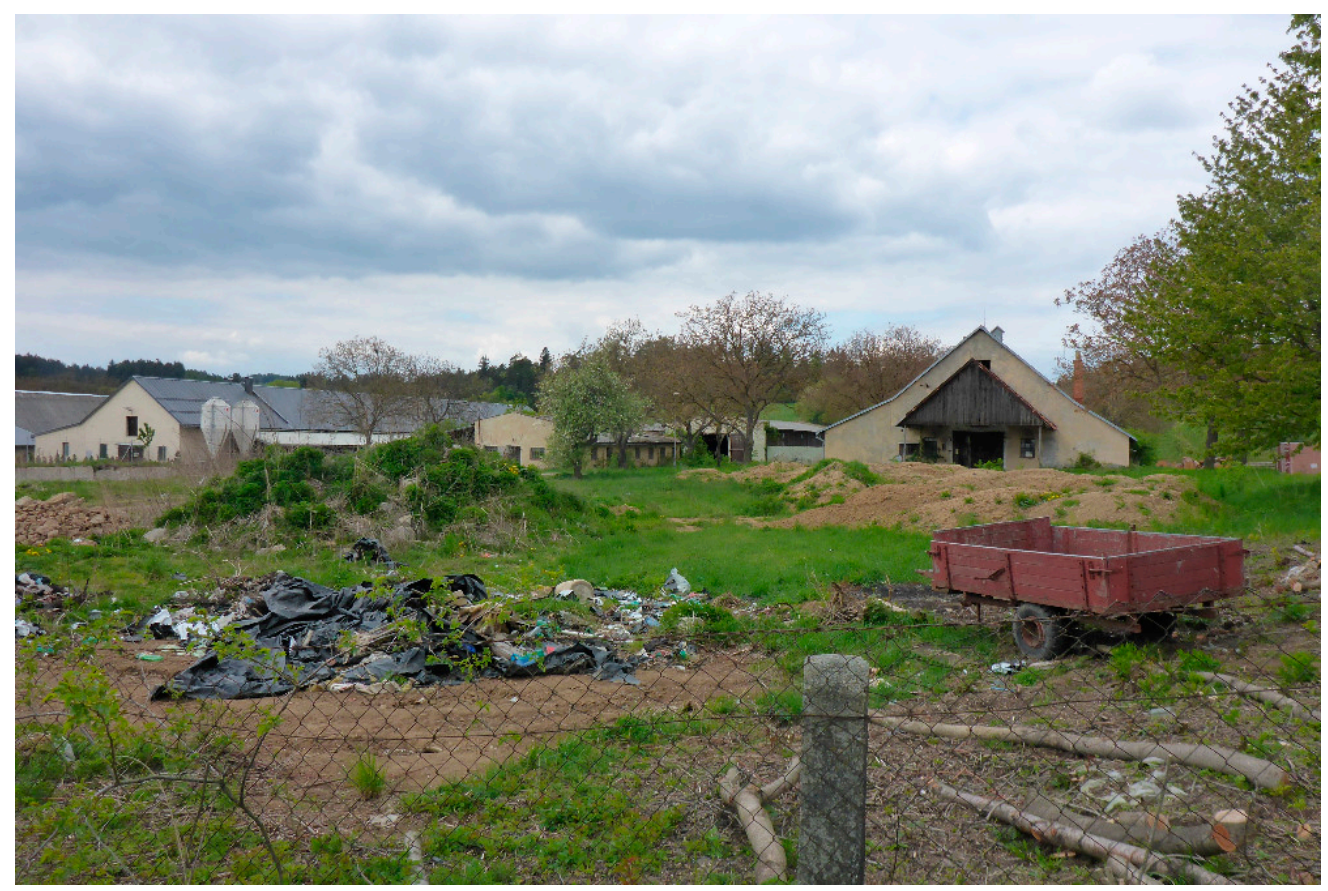

Figure 1. Typical view on abandoned cowsheds. Photo taken by authors.

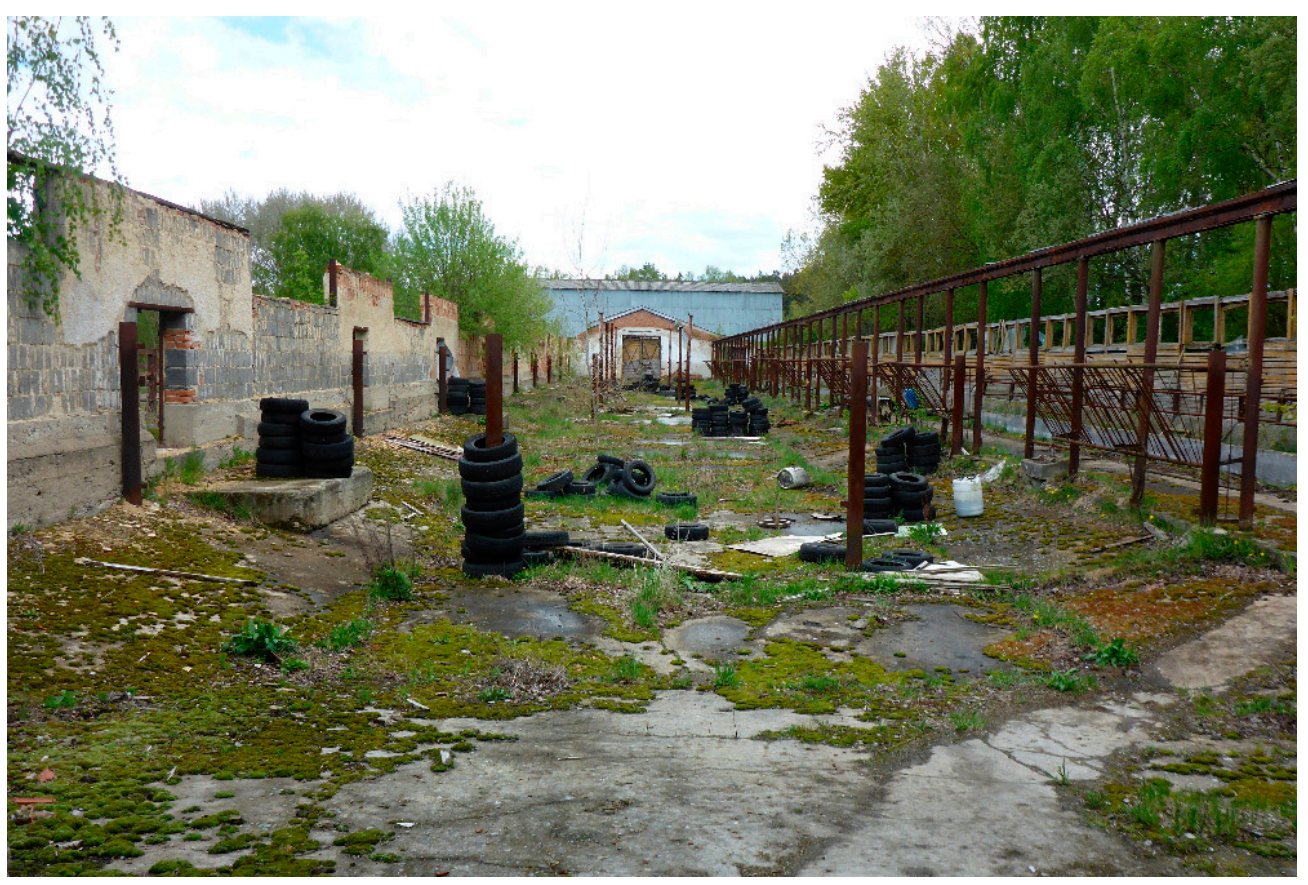

Figure 2. Interior of a former cowshed. Photo taken by authors.

Dramatic changes in the utilization of agricultural premises during the restitution and privatization processed since 1991, followed by substantial cuts of governmental subsidies to agriculture since 1993, resulted in the restructuring of the whole agricultural sector. These huge changes might be mirrored in the intensive fall in agricultural employment and drops of the share of agricultural production on GDP [17]. These processes resulted in the completely changed economic structure of Czech rural areas in comparison to times before 1989. Privatization and restitution of agricultural land and properties 
were extremely fast in the case of the Czech Republic and resulted in millions of new landowners. However, the assumption of the quick growth of commercial family farms was not fulfilled [33]. The majority of original small landowners already died, or their heirs frequently moved to cities and were not interested in practicing agriculture. Thus, agricultural land has been cultivated especially by great companies $[34,35]$ that hire or buy up land. Only about $13 \%$ is cultivated by family farmers [17].

Besides large agri-companies, plenty of collective farms still exist but with a changed legal status [33]. These collective farms have generally been transformed into corporate types of farms that are enterprises with the legal labels of partnerships, joint-stock companies, or limited liability companies. However, corporate farms were suffering from low profitability, high debts, and high liquidation or bankruptcy rates [36], which resulted in a decrease in their numbers [35]. Economically not so effective organizational structures of agricultural companies and changes in land ownership and a general decrease of agriculture [37] led to the occurrence of a range of unused or underused buildings and premises in rural space [18]. They are usually large-scale (e.g., barns, grain silos, storehouses, mill houses, cowsheds, calf houses, pigsties, etc.). They also pose a meager investment potential and are not immediately exploitable [19]. It would be difficult to use them by the usage of modern agricultural technologies and due to their location in marginal regions away from developing areas [18]. According to a survey of the CzechInvest Agency, abandoned sites after agriculture are the most numerous out of all abandoned sites in the Czech Republic [27].

The majority of formerly abandoned buildings that are currently utilized are only temporarily used for provisional activities [14]. Such underutilization is most often represented by small-scale manufacturing or investments in facilities for tourism, recreation, or culture (horse farms, hotels, tourist centers, museums, etc.) [38]. It has to be stressed that re-use of agricultural properties after a period of abandonment is very difficult due to the rapid deterioration of the technical state of buildings and due to processes of modernization or specialization that are taking place in agriculture [18]. Usually, smaller properties with a higher level of connectivity and accessibility are more often regenerated [39]. It is also well known that regenerations of properties are much more frequent in urban than in rural areas [40]. It also seems to be proved that good accessibility is a basic element for investors when deciding which one of the available premises will be regenerated [41].

Some spatial differences in current uses and abandonment of rural farm premises were found in case studies dealing with changes in their uses in selected regions within South Bohemia [14]. They found significant differences in the share of agricultural use, non-agricultural uses, and abandonment between regions. By conducting our research, we endeavor to detect which socio-economic and agri-natural characteristics of the location of agricultural premises are important in recycling the use of communist rural farm premises.

\section{Materials and Methods}

Two neighboring NUTS 3 regions (3rd level of region according to Nomenclature of Territorial Units for Statistics of the EU) were chosen as study areas-the South Moravian Region and the South Bohemian Region. These regions were chosen because they represent two different agricultural types of regions. Both regions are considered as "agricultural." The South Moravian Region is "agricultural" as it has the best preconditions for in the Czech Republic [42]. On the other hand, the South Bohemian Region is a sparsely populated rural area and "agricultural" because it was not intensively industrialized [43].

South Moravia (especially the southern part) has more favorable conditions for agriculture-accessible relief, quality soils, and a warm and dry climate [44]. These characteristics gave one of the foundations for large-scale agriculture with large areas of agricultural cooperatives after the Second World War. Thanks to suitable natural conditions, the South Moravian Region is a suitable area for growing mainly cereals and vines; an important segment of agricultural production is also growing fruit $[45,46]$. However, due to the longer-lasting lack of precipitation, the yield per hectare for most crops has rather decreased in recent years. Of animal production, poultry farming is important (together with the 
Pardubice Region), less so of pigs and dairy cattle (these two commodities decreased significantly after 2010) [47]. On the other hand, the South Bohemian Region has a somewhat more rugged relief (perhaps except for the Třeboň and České Budějovice basins), which crosses the foothills and mountain landscapes in the southern part, which also results in a colder climate [42]. The lower fertility of soils, partly limiting the cultivation of crops, is replaced by an extensive network of water bodies (eastern and south-eastern parts of the region), creating suitable conditions for poultry farming and a specific segment of fisheries. From animal production, the most important is cattle breeding (most in the Czech Republic), especially meat breeds. Due to natural conditions and historical development, smaller agricultural compounds predominate here [42], with a few exceptions, rather than in the South Moravian Region [29].

Two types of data had to be gathered to accomplish the aim of the study. Firstly, the locations of the pre-1989 rural farm premises with current uses were necessary to identify. Secondly, data on agri-natural and socio-economic characteristics of municipalities where rural farm premises are located had to be gathered.

\subsection{Location and Current Use of the Pre-1989 Rural Farm Premises}

The identification of the pre-1989 rural farm premises followed the methodology of Navratil et al. [6]. The topographic maps of Czechoslovakia with a scale of 1:25,000 from the late 1980s and the first mid-1990s were used. The sites considered to be the pre-1989 rural farm premises were labelled in these maps as [20]: agricultural properties, cowsheds, pig farms, sheepfolds, poultry farms, horticultural fields, and stud farms. Black and white prints of the aerial images from the early 1990s were used to delimit the borders of these properties. For accuracy of the spatial data used, the analyses of utilization and changes in utilization were conducted with an accuracy of $10 \times 10 \mathrm{~m}$ square.

There are not many choices on obtaining data on the current use of the pre-1989 rural farm premises for such a large study area. We decided to use aerial images that are freely accessible-aerial imagery for the current use were taken between the years 2016 and 2018. The preparation of data also followed the methodology of Navratil et al. [14]—one WMS service of the Czech Office for Surveying, Mapping, and Cadastre was used: WMS-Orthophoto, ver 2.0. For the current use, a verification of this procedure was undertaken on 200 randomly selected premises that had been visited. Based on aerial imagery data, we were able to distinguish among six categories of usage:

- Agricultural utilization,

- Non-agricultural utilization (utilization for entrepreneurship but not agricultural, including photovoltaic power plants),

- Housing,

- Cultivated agricultural land (land ploughed, used for grazing or regularly mowed),

- Rural derelict farm premises (abandoned premises, brownfields).

The spatial extent of the communist rural farm premises has increased in some cases since then, but this space enlargement was not taken into account for this study.

\subsection{Data on Agri-Natural and Socio-Economic Characteristics of Municipalities Where Rural Farm Premises Are Located}

Municipalities were selected for our research as the spatially smallest units with available data that were usable for our proposed aim. The selection of indicators was made according to previous studies aimed at agricultural change [48] and typology of the development potential of the countryside [49].

We used four types of data for agri-natural characteristics of municipalities:

- The areas of agricultural production (AAP) are the most important characteristic of natural conditions for agriculture as they characterize the agri-cultural conditions of a given area from the point of view of the soil quality and climatic conditions. Based on the Regulation of the 
Ministry of the Treasury of the Czech Republic no. 178/1994 and the Regulation of the Ministry of Agriculture of the Czech Re-public no. 215/1995, five basic areas of agricultural production were delimited (corn AAP, sugar beet AAP, grain AAP, potatoes AAP, and fodder crops AAP), along with 21 subtypes within the basic areas. In our evaluation, only the five basic areas of agricultural production were taken into account, as in Martinat et al. [48]-thus, this is a nominal variable with five levels.

- The average basic administrative (not market) price of agricultural land in CZK is given in regulations no. 298/2014 and no. 318/2019. We used this data as an indicator of the average quality of agricultural soils in the area of the given municipality. We have to stress that the administrative price of agricultural land is different from marked prices. On the other hand, for our purposes, it is crucial that it was set on the same methodology for the whole area of the Czech Republic, and thus, it is a comparable indicator among all municipalities.

- Land use data [50] for the level of municipalities based on data for cadastres available from the Czech Statistical Office as territorial analytical data was based on Regulation no. 500/2006. Two datasets were used: (i) data for the year 2018 and (ii) the change between the year 2019 and the oldest available comparable data (the year 2009). Land use classes used are as follows: agricultural land, arable land, pastures and meadows, woodland, forests, waters, built-up areas. We have used the share of each class in the area municipality for our analyses.

- The coefficient of ecological stability was utilized. The coefficient is calculated as the ratio between land use classes that are considered as ecologically stable (such as orchards, meadows, forests, waters), and land use classes that are considered as ecologically non-stable (built-up areas, roads, arable land) [51]. The source of data is the same as land use data and data for the year 2019 as well as the source of data for the change in land use between the years 2018 and 2009.

Socio-economic data for the level of municipalities are derived from Perlin et al. [49], as proposed by Martinat et al. [48]. Thus, indicators for four factors of rural development (size, population growth, human potential, and housing) were used as follows: population number (2018), population change (calculated as 2018/2005, in \%), average age (2018), change of the average age (calculated as 2018-2005), share of young people up to 15 years old in population (2018), share of young up to 15 on population change (calculated as 2018-2005), share of inhabitants older than 60 years on population (2018), share of inhabitants older than 60 years on population change (calculated as 2018-2005), age index (2018), age index change (calculated as 2018-2005), net migration (2012), share of native population in municipality (2011, in \%), participation in elections (2010), share of houses built or reconstructed (2001/2011, in \%), share of population with maximum primary education (2011, in \%), share of population with university education (2011, in \%), share of the economically active population in agriculture, forestry, and fisheries (2011, in \%), and the share of the economically active population in accommodation, food services, and hospitality (2011, in \%).

The following abbreviations were used in Figure 4: age_i_ch = age index change; built_up = built up areas from land use data; pastures_meadows = pastures and meadows from land use data; primary_econ = share of the economically active population in agriculture, forestry, and fisheries; univ_education $=$ the share of population with tertiarry education; water $=$ waters from land use data.

\subsection{Data Handling and Analyses}

We have prepared three datasets for each municipality with rural farm premises in 1989 in two regions.

Firstly, the share of each type of use in the year 2018 of the area of the pre-1989 rural farm premises was calculated. This will be the multiple dependent variables in our analyses-this variable consists of five variables (agricultural utilization, non-agricultural utilization, housing, cultivated agricultural land, and rural derelict farm premises).

Secondly, we have prepared data for agri-natural characteristics. This is our first set of independent variables encompassing 18 variables (areas of agricultural production; average basic price of agricultural 
land; the share of seven land-use categories on the area of the municipality and its change-agricultural land, arable land, pastures and meadows, woodland, forests, waters, built-up areas; coefficient of ecological stability-present value and its change).

Thirdly, we have prepared data for socio-economic characteristics. This is our second set of independent variables encompassing also 18 variables (population number, population change, average age, average age change, share of young up to 14 on population, the share of young up to 14 on population change, the share of inhabitants older than 65 years on population, the share of inhabitants older than 65 years on population change, age index, age index change, net migration, the share of the native population, participation in elections, the share of houses built or reconstructed, the share of the population with maximum primary education, the share of the population with a university education, the share of the economically active population in agriculture, forestry, and fisheries, and the share of the economically active population in accommodation, food services, and hospitality).

As we would like to find out which socio-economic and agri-natural characteristics are behind different uses of pre-1989 rural farm premises and there is more than one variable on both left-hand and right-hand sides, multivariate techniques $[52,53]$ to solve our proposed issue have to be used. Linear or non-linear techniques can be used. The use of one of those types is the question of choice and is dependent on the length of gradient expressed in standard deviation units of data [54]. As the length of the gradient of our data is quite long (3.3 SD) and many nulls are present (as not all types of use are present in many municipalities), a non-linear technique was selected for data analysis. To accomplish the aim of our paper by testing the impact of independent variables on dependent variables, a constrained method had to be used [54]. Thus, constrained canonical analysis (CCA) as the most appropriate statistical method was used [55]. Since we assume that not all independent variables have to be statistically significant for the structure of the current uses of pre-1989 rural farm premises, the CCA with the forward selection of independent variables was used. The forward selection was based on the Monte Carlo permutation test [55] testing a hypothesis of the non-existence of differences between the structure of real data and the structure of randomly arranged values from those data [56]; 999 permutations (i.e., 999 randomly arranged data) were used. A generalized additive model with Gaussian response distribution was used to test and the response curves plot was used to visualize the importance of the first two CCA axes for all dependent variables. The correlation (at $p<0.01)$ for statistically important independent variables between scores on the first two canonical axes and measured values for all municipalities was used for the identification of independent variables important for both axes. As two sets of independent variables were prepared, we could test them separately and assess their importance for the structure of re-uses of pre-1989 rural farm premises-variation partitioning for two groups was used to identify the importance of those two groups of dependent variables (socio-economic and agri-natural) and their joined importance. All calculations of multidimensional analyses were done with the software CANOCO 5.0 [55]; the implemented tool Var-part-2groups-Simple-effect was used for Variation Partitioning [55].

\section{Results}

According to the results of the generalized additive model, the most important dependent variable for the first CCA axis is agriculture, which goes against non-agricultural uses and brownfields (Figure 3a). These three variables are significant and the most important were found to be agriculture that explains $15.2 \%$ and non-agricultural use, which explains $11.7 \%$ of the variability (Table 1 ). The second CCA axis is given by brownfields and cultivated land whose importance decreases with the increasing importance of housing and non-agricultural uses (Figure 3b). According to the variability explained, the most important were brownfield, housing, and cultivated land (Table 2). 


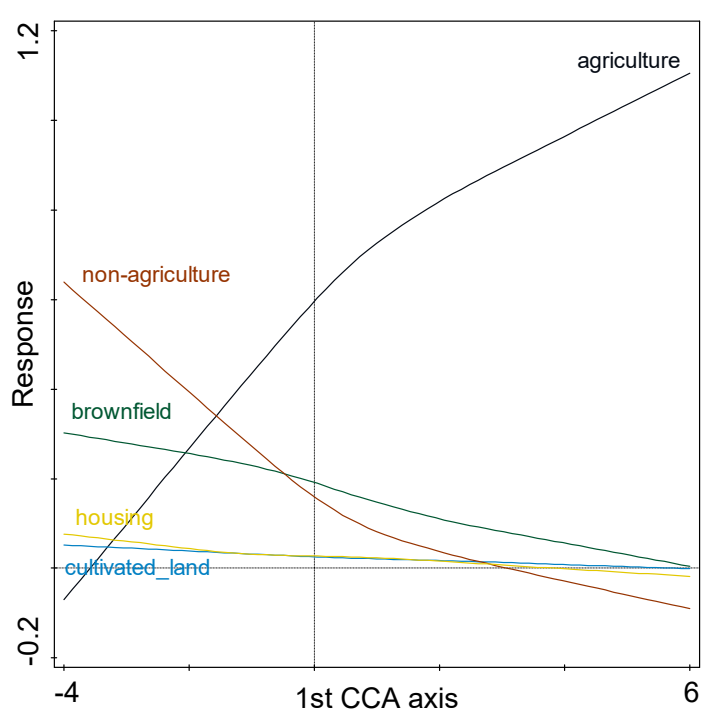

(a)

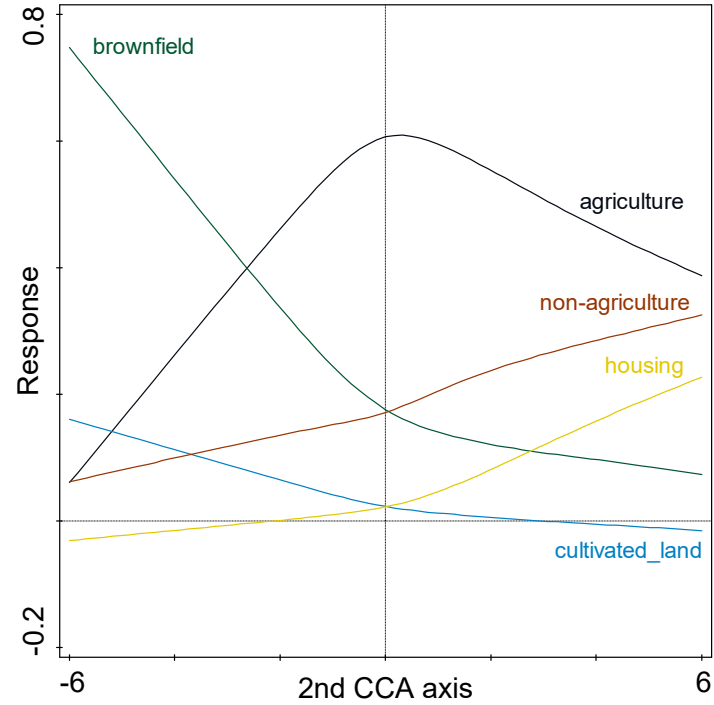

(b)

Figure 3. Response curves of all dependent variables according to first CCA axis (graph on the left, a) and second CCA axis (graph on the right, b); results of the generalized additive model.

Table 1. Summary of fitted Generalized Additive Models for all five dependent variables-first constrained canonical analysis (CCA) axis.

\begin{tabular}{ccc}
\hline Response Variable & $\mathbf{R}^{\mathbf{2}}[\%]$ & $\mathbf{F}$ \\
\hline agriculture & 15.2 & $109.1^{* * *}$ \\
\hline cultivated land & 0.5 & $3.2^{*}$ \\
\hline brownfield & 2.6 & $16.5^{* * *}$ \\
\hline non-agriculture & 11.7 & $80.6^{* * *}$ \\
\hline housing & 0.5 & 2.8 \\
\hline
\end{tabular}

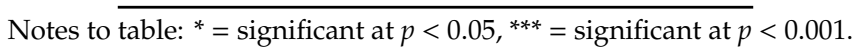

Table 2. Summary of fitted Generalized Additive Models for all five dependent variables—second CCA axis.

\begin{tabular}{ccc}
\hline Response Variable & $\mathbf{R}^{\mathbf{2}}[\%]$ & $\mathbf{F}$ \\
\hline agriculture & 3.2 & $20.4^{* * *}$ \\
\hline cultivated land & 4.6 & $29.6^{* * *}$ \\
\hline brownfield & 5.9 & $38.0^{* * *}$ \\
\hline non-agriculture & 1.2 & $7.4^{* * *}$ \\
\hline housing & 4.9 & $31.1^{* * *}$ \\
\hline
\end{tabular}

Notes to table: ${ }^{* * *}=$ significant at at $p<0.001$.

The correlation between axes scores and measured values for all independent variables found by the forward selection CCA procedure shows us the most important independent variables for the first two axes (Table 3). The most important factors for the first CCA axis that separated agricultural and other uses (especially non-agricultural uses) were found to be primary economic activities, including the share of pastures and meadows, land price, and location in corn AAP or potatoes AAP (Table 3). The most important factors for the second CCA axis that separated agricultural brownfields and cultivated land from housing and non-agricultural uses were found to be population share, primary education share, university share, and location in corn AAP (Table 3). 
Table 3. Correlation between scores and measured values for all variables in the CCA model.

\begin{tabular}{ccc}
\hline & 1st Axis & 2nd Axis \\
\hline population change & $-0.12^{* * *}$ & $0.19^{* * *}$ \\
\hline election & $\mathrm{ns}$ & $0.14^{* * *}$ \\
\hline young share & $-0.07^{*}$ & $0.08^{* *}$ \\
\hline young share change & $\mathrm{ns}$ & $0.06^{*}$ \\
\hline old share & $0.11^{* * *}$ & $-0.07^{*}$ \\
\hline age index change & $\mathrm{ns}$ & $\mathrm{ns}$ \\
\hline native share & $\mathrm{ns}$ & $-0.08^{* *}$ \\
\hline primary education share & $0.11^{* * *}$ & $-0.19^{* * *}$ \\
\hline university education share & $-0.13^{* * *}$ & $0.19^{* * *}$ \\
\hline primary economic activity share & $0.33^{* * *}$ & $\mathrm{~ns}$ \\
\hline pastures and meadows & $0.20^{* * *}$ & $0.07^{*}$ \\
\hline built up areas & $-0.14^{* * *}$ & $0.07^{*}$ \\
\hline waters & $\mathrm{ns}$ & $\mathrm{ns}$ \\
\hline land price & $-0.22^{* * *}$ & $-0.12^{* * *}$ \\
\hline corn AAP & $-0.31^{* * *}$ & $-0.23^{* * *}$ \\
\hline potatoes AAP & $0.25^{* * *}$ & $0.08^{*}$ \\
\hline grain AAP & $\mathrm{ns}$ & $0.09^{* *}$ \\
\hline fodder crops AAP & $0.19^{* * *}$ & $0.13^{*}$ \\
\hline sugar beet AAP & $-0.16^{* *}$ & $\mathrm{~ns}$ \\
\hline sigicant at $p<0.05, * *$ significant at $p<0.001^{* * *}=$ significant at $p<0.001, \mathrm{~ns}$ \\
\hline
\end{tabular}

Notes to table: ${ }^{*}=$ significant at $p<0.05,{ }^{* *}=$ significant at $p<0.001,{ }^{* * *}=$ significant at $p<0.001, \mathrm{~ns}=$ not significant.

Position of five analyzed uses of pre-1989 rural farm premises in first two dimensions of CCA plot confirm the results obtained from the generalized additive model — the first axis represents agricultural versus other types of uses, and along the second axis re-uses for housing from abandonment or re-cultivations were separated (Figure 4). The types of re-uses are influenced by independent characteristics of municipalities, with the location of pre-1989 rural farm premises as many of the variables chosen by the forward selection in CCA were statistically important for the structure of re-uses. The total variation explained by the CCA model was $7.8 \%$, which is not very high, but it is usual in this type of study [57]. Fifteen variables (visualized in Figure 4) out of 36 were found to be statically important, which means that $42 \%$ of independent variables are important. Based on the above, we can be sure that the links between the re-use of pre-1989 rural farm and the type of municipality exist. We declare that these significances are not a result of "statistical fishing" [58].

Based on the CCA biplot (Figure 4), we can assume that agricultural use or re-use can be primarily found in municipalities located in the fodder crops and potatoes AAPs. In these municipalities, we found the highest shares of permanent grassland on agricultural land. The shares of people working in agriculture was higher here, as well as the share of people older than 65 years. The population is ageing in these municipalities. The non-agricultural production can be found in municipalities in the sugar beet AAP, where we detected higher shares of built-up areas. In these municipalities, a growing number of people younger than 14 years were also found, and a higher price of agricultural land was revealed. As for a share of people working in the primary sector of the economy and older people, this was rather low in this case. On the contrary, the housing re-use was more likely in the case of municipalities with a high share of people with university education and a low share of people with only basic education. In these municipalities, high population growth until the year 2018 was detected. People in these municipalities tend to participate more in elections and are rather located in the fodder crops AAP. Re-use into arable land with a higher probability that brownfield will occur was found in 
the case of municipalities with a high price of agricultural land in the corn AAP where the share of young people was low. The share of people with only basic education was high.

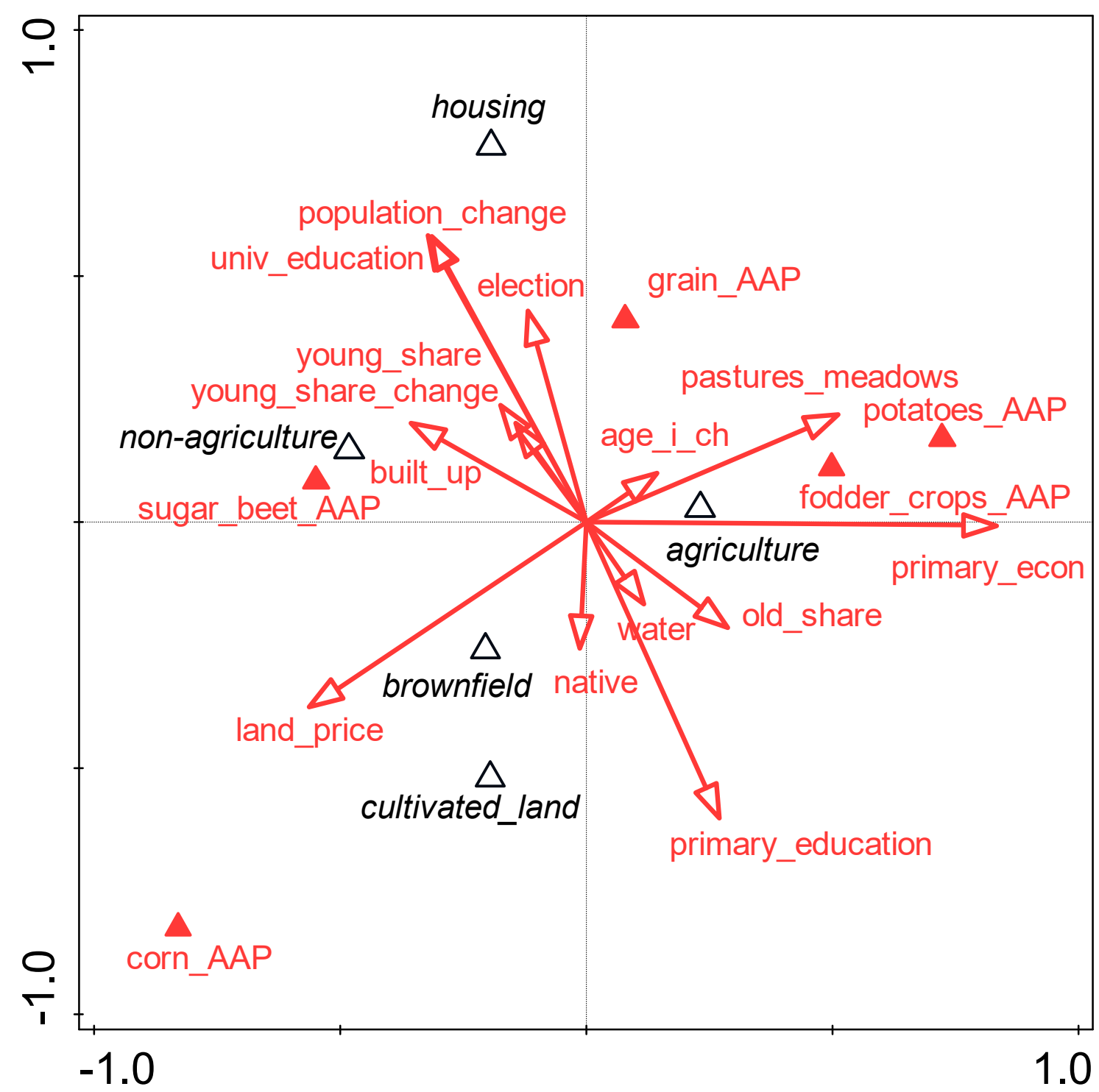

Figure 4. Biplot of dependent and independent variables; results of CCA with the forward selection of independent variables entered in the model.

Circa one-fourth of explained variation can be explained by the joint influence of both groups of variables (Table 4, Figure 5). The socio-economic variables are more important for differentiation of re-uses of pre-1989 rural farm premises-they explain $54.4 \%$ of total explained variation. If we measure the impact of agri-natural characteristics independently, it is relatively smaller (only 19.7\%).

Table 4. Results of Variation Partitioning (comparison of two simultaneous CCA).

\begin{tabular}{cccccc}
\hline Fraction & Variation (adj) & \% of Explained & \% of All & d.f. & Mean Square \\
\hline socio-economic & 0.067637 & 54.4 & 4.3 & 10 & 0.00792 \\
\hline agri-natural & 0.024507 & 19.7 & 1.5 & 8 & 0.00424 \\
\hline Join & 0.032258 & 25.9 & 2.0 & - & - \\
\hline total explained & 0.1244 & 100.0 & 7.8 & 18 & 0.00811 \\
\hline
\end{tabular}


factors of changes in use

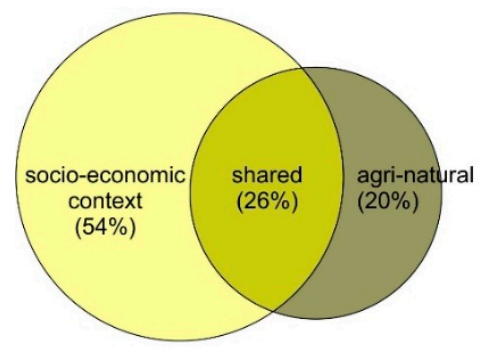

uses of socialist agricultural premises in 2018

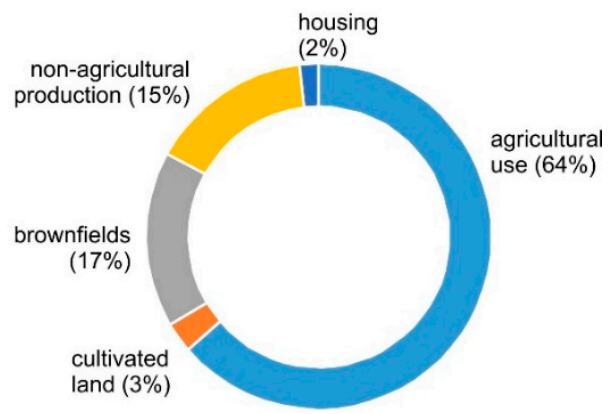

Figure 5. The summarized result of variation portioning and its impact on the structure of uses of pre-1989 agricultural premises.

\section{Discussion and Conclusions}

In our research, the analyses of large datasets on the contemporary use of pre-1989 rural farm premises (Figure 6) and consequent socio-economic and agri-natural variables (Figure 5 ) undoubtedly revealed interesting results (Figure $3 \mathrm{a}, \mathrm{b}$ and Figure 4).

Our results shine more light on a complex problem of recurring use of spacious agricultural premises [14] that originated during collectivization in the most affected country by the collectivization among CEEs [16].

We have ascertained that the current utilization of agricultural premises is not just the result of the change in property rights and entrepreneurial creativity $[18,19]$, but is rather dependent on the socio-economic context. In other words, we contributed to the identification of many general factors (Tables 1-3) that influence the contemporary use of agricultural premises. There is no doubt that these problematic sites might be perceived as the legacy of the planned linear economy that has been reshaped by the linear market economy when abandoned $[16,18,20]$ and finally influenced by an environmentally more beneficial circular economy approach when re-used [19]. We understand now the re-use of agricultural premises in the wider context of recycling of previously used and abandoned sites [59].

Each of the five types of re-use is connected to other, in some cases contradictory, conditions (Table 3). Based on the results of variation partitioning (Figure 4), we can say that the contemporary use of agricultural premises mirrors overall changes in rural society [2,4]. We can also stress that the contemporary use of analyzed premises signals a certain level of the link to general processes that affect the rural [49]. We have found that different types of abandonment, uses, and re-uses are interconnected with different socio-economic and agri-natural variables (Figure 4). Among these ties, we can put stress especially on four-areas with remaining agriculture, areas that lost agricultural uses, areas with remaining agriculture, and areas without uses. As this knowledge is new, we will further try to find the consequences of our findings. 


\section{SOUTH BOHEMIAN REGION}
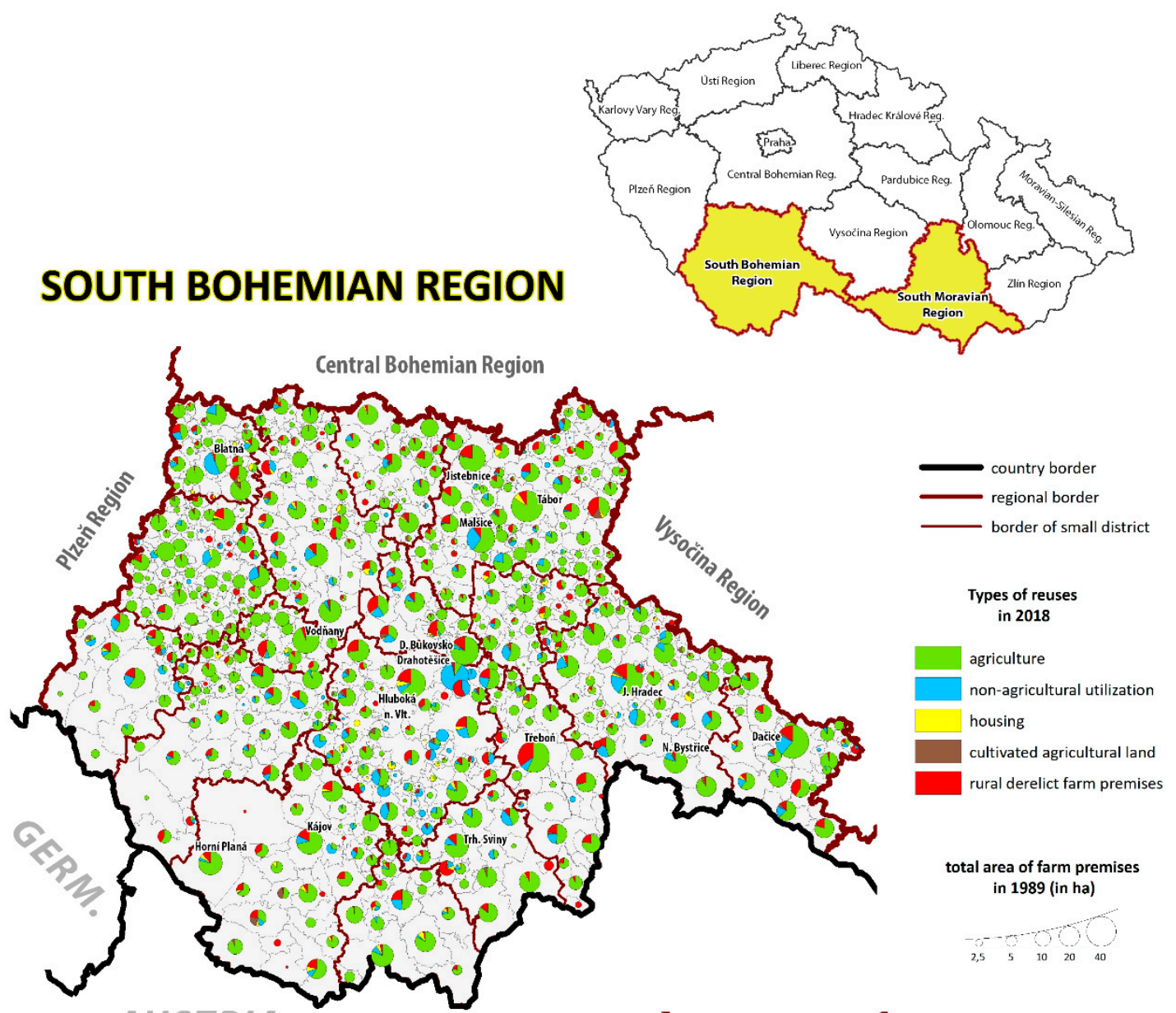

AUSTRIA
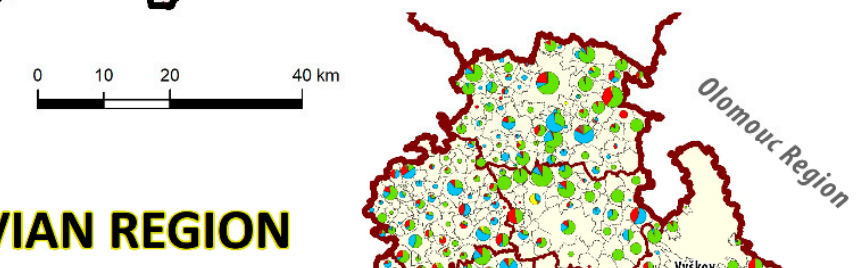

SOUTH MORAVIAN REGION

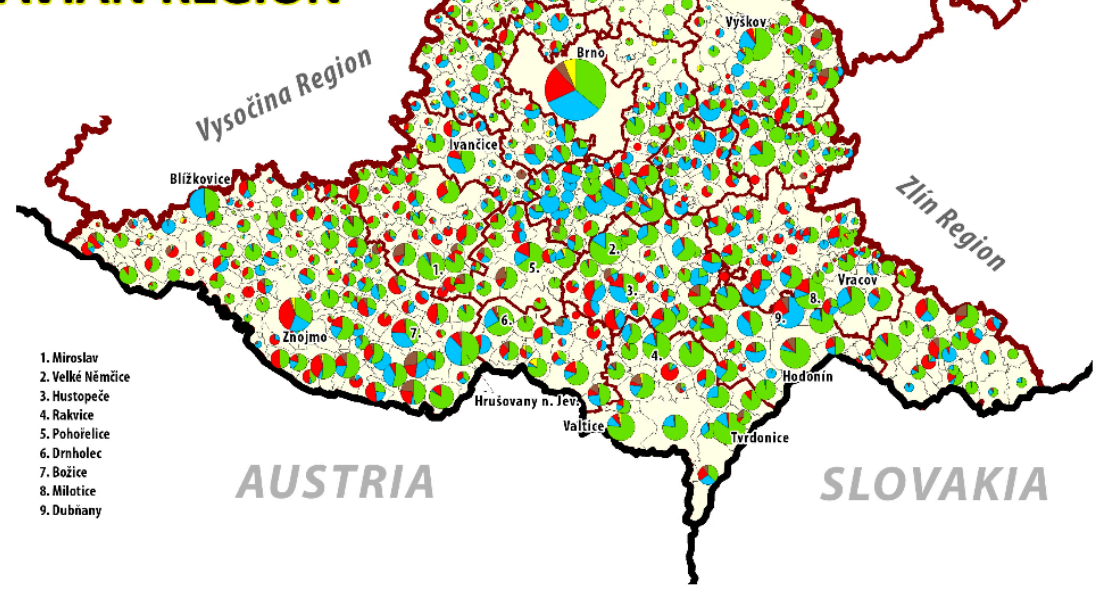

Figure 6. Study area with uses of pre-1989 agricultural premises in 2018. Data for municipalities.

First, we draw our attention to sites where agricultural uses survived. This is the case of the marginal areas from the agricultural point of view (the potatoes and fodder crops AAPs) that are less suitable for agricultural activities. The results for these municipalities positively correlate with a high share of employment in agriculture, with a high share of the older population and, on the 
contrary, is negatively correlated with a share of built-up areas (Table 3, Figure 4). Thus, our results show that remaining agricultural uses are located in "peripheral" areas [13,29]. These municipalities might be described as the regions with a traditionally weaker economic performance that currently live more on agricultural subsidies than from the results of their economic activity $[5,12]$. It is quite a paradoxical result that the transition for non-agricultural re-use is typical in those areas that are situated in more suitable natural conditions for agriculture (located in the sugar beet AAP). Secondly, non-agricultural business activities were found by our model as the most important opposite to agricultural uses (along with the first CCA axis, Figure 4) as well as differences between housing (with non-agricultural uses) and agricultural brownfields (second CCA axis, Figure 4). Previous studies show us that while in the areas close to attractive urban spaces, farmers sell farms and land at a high price; in the periphery, they rather resigned from agricultural production [60] and shifted their activities more toward non-agricultural activities. The pressure of urban centers to change the use of the land in their neighborhoods [61,62] and change the lifestyle in the countryside [63] had an enormous impact on the uses (and re-uses) of agricultural premises in the studied area [64]. Our results of factors correlating with agricultural versus non-agricultural uses (Table 3 ) show us that the urban-rural pattern predominantly affected also the uses of pre-1989 agricultural premises. The other issue is the issue of housing, found in our study as most important for the second CCA axis (Figure 4). This is evidence of gradual change of the primary function of the Czech countryside from agriculture to housing in the last three decades $[49,65]$. Housing as a type of re-use belongs to the noteworthy effects of the transition of agricultural premises as it positively influences the deceleration of taking up the greenfields [64]. This effect is enormously vital in the vicinity of larger urban centers where the occurrence of urbanization processes is strong $[63,66]$. Housing sometimes may also be the only option when considering the re-use of otherwise unusable buildings [67]. It is evident that the regeneration of old agricultural premises or brownfields into housing runs into numerous health, safety, and technical problems [68], but the assistance of the public sector may undoubtedly help in overcoming the issues.

The third important issue for discussion of our results is agricultural derelict properties. The areas with the largest share and the occurrence of agricultural brownfields seem to be the most specific (Figure 4). It is obvious that in these cases, the regeneration attempts failed so far [18], and given premises are still waiting for the new re-use. We would find these sites primarily in the areas with the greatest quality land that is typically the highest land price located within the corn AAP (Table 3, Figure 4). These municipalities might be characterized by a higher share of people born in the municipality and, thus, a low level of immigration (Table 3, Figure 4). In the vast majority of cases, we are talking about the most fertile areas of South Moravia [49,69] defined as "equipped Moravian countryside" according to the typology of the Czech countryside [49]. These agricultural premises were relatively larger due to their economic importance (and the location) than less-favored areas for agriculture [21]. Within these farms, the breeding stations were frequently located and especially supported by central governmental bodies. We can also say that the small-scale agricultural activities could be seen in these areas even during the Communist era (e.g., small-scale viticulture, etc.) $[13,45,70]$. Such specificity enabled small farmers to work again on their fields after the end of the restitution process in the 1990s. On the other hand, large farms (the lessors of agricultural land) were made to concentrate and specialize in their agricultural activities so that they could survive hard times [12]. This is the research direction that we would like to devote our time to in the future. It might reveal another hidden dimension of the agricultural transition in the Czech Republic as the country whose agricultural sector was the most affected by the collectivization process that is still accountable for many challenges of today's Czech agriculture.

Author Contributions: Conceptualization, J.N. and T.K.; methodology, J.N. and S.M.; formal analysis, K.P. and P.K.; resources, J.Š. and R.O.; data curation, J.N. and T.K.; writing-original draft preparation, J.N., T.K. and S.M.; writing - review and editing, K.P., P.K. and R.O.; visualization, T.K. and J.N.; funding acquisition, J.N. All authors have read and agreed to the published version of the manuscript. 
Funding: This work was supported by project No. 19-23870S funded by the Czech Science Foundation under the title Between de-agrisation and perforated development of rural space: The search for development patterns of post-communist agricultural properties.

Conflicts of Interest: The authors declare no conflict of interest. The funders had no role in the design of the study; in the collection, analyses, or interpretation of data; in the writing of the manuscript, or in the decision to publish the results.

\section{References}

1. Bonfiglio, A.; Camaioni, B.; Coderoni, S.; Esposti, R.; Pagliacci, F.; Sotte, F. Are rural regions prioritizing knowledge transfer and innovation? Evidence from Rural Development Policy expenditure across the EU space. J. Rural Stud. 2017, 53, 78-87. [CrossRef]

2. Jancak, V.; Eretova, V.; Hrabak, J. The Development of Agriculture in Czechia After the Collapse of the Eastern Bloc in European Context. In Three Decades of Transformation in the East-Central European Countryside, 1st ed.; Banski, J., Ed.; Springer: Cham, Switzerland, 2019; pp. 55-72.

3. Van der Horst, D.; Martinat, S.; Navratil, J.; Dvorak, P.; Chmielova, P. What can the location of biogas plants tell us about agricultural change? A Case Study from the Czech Republic. Deturope-Cent. Eur. J. Reg. Dev. Tour. 2018, 10, 33-52.

4. Vaishar, A.; Stastna, M. Development of the Czech Countryside After 1990: Causes and Consequences. In Three Decades of Transformation in the East-Central European Countryside, 1st ed.; Banski, J., Ed.; Springer: Cham, Switzerland, 2019; pp. 99-118.

5. Veznik, A.; Bartosova, L. Selected regional geographical differences of the Czech Republic agriculture, after the transformation processes. Agric. Econ. 2004, 50, 207-216.

6. Chodkowska-Miszczuk, J.; Kulla, M.; Novotny, L. Biogas energy-A chance for agriculture and rural development? Insight from the post-communists Central Europe. Deturope-Cent. Eur. J. Reg. Dev. Tour. 2019, 11, 30-53.

7. Mezei, K.; Trojan, S.; Lipcseine Takacs, N. The grass is always greener on the other side, or else Austria through the eyes of european rural developers. Deturope-Cent. Eur. J. Reg. Dev. Tour. 2018, 10, 199-213.

8. Midmore, P. Agricultural science research impact in the Eastern European Union Member States. Stud. Agric. Econ. 2017, 119, 1-10. [CrossRef]

9. Banski, J. Phases to the transformation of agriculture in Central Europe-Selected processes and their results. Agric. Econ.-Zemed. Ekon. 2018, 64, 546-553. [CrossRef]

10. Csatari, B.; Farkas, J.Z.; Lennert, J. Agrarian and Rural Development in Hungary After 1989. In Three Decades of Transformation in the East-Central European Countryside, 1st ed.; Banski, J., Ed.; Springer: Cham, Switzerland, 2019; pp. 21-54.

11. Banski, J. Spatial Differences in the Transformation Processes Taking Place in Rural Areas of East-Central Europe. In Three Decades of Transformation in the East-Central European Countryside, 1st ed.; Banski, J., Ed.; Springer: Cham, Switzerland, 2019; pp. 3-20.

12. Veznik, A.; Kral, M.; Svobodova, H. Agriculture of the Czech Republic in the 21st century: From productivism to post-productivism. Quaest. Geogr. 2013, 32,7-14. [CrossRef]

13. Konecny, O. Spatial polarization of agriculture of Czechia during the integration into the European Union. Geografie 2017, 122, 257-280. [CrossRef]

14. Navratil, J.; Martinat, S.; Krejci, T.; Picha, K.; Klusacek, P.; Skrabal, J.; Osman, R. The fate of socialist agricultural premises: To agricultural 'brownfields' and back again? Morav. Geogr. Rep. 2019, 27, 207-216. [CrossRef]

15. Bański, J. Agriculture of Central Europe in the period of economic transformation. In Contemporary Changes of Agriculture in East-Central Europe; Bański, J., Bednarek, M., Eds.; Polish Geographical Society: Warsaw, Poland, 2008.

16. Klusacek, P.; Krejci, T.; Martinat, S.; Kunc, J.; Osman, R.; Frantal, B. Regeneration of agricultural brownfields in the Czech Republic - Case study of the South Moravian Region. Acta Univ. Agric. Et Silvic. Mendel. Brun. 2013, 61, 549-561. [CrossRef]

17. Doucha, T.; Divila, E. Changes in Czech Agriculture in the Years 1990-2005. In Contemporary Changes of Agriculture in East-Central Europe; Bański, J., Bednarek, M., Eds.; Polish Geographical Society: Warsaw, Poland, 2008; pp. 73-96. 
18. Skala, J.; Cechmankova, J.; Vacha, R.; Horvathova, V. Varios aspects of the genesis and perspectives on agricultural brownfields in the Czech Republic. Morav. Geogr. Rep. 2013, 21, 46-55.

19. Svobodova, H.; Veznik, A. To the problems of agricultural brownfields in the Czech Republic - Case study of the Vysocina region. Agric. Econ.-Zemed. Ekon. 2009, 55, 550-556. [CrossRef]

20. Krejci, T.; Navratil, J.; Martinat, S.; Picha, K.; Klusacek, P.; Osman, R.; Skrabal, J. Current use of former communist agricultural properties in South Bohemia. In Proceedings of the 22nd International Colloquium on Regional Sciences. Conference Proceedings, Velke Bilovice, Czech Republic, 12-14 June 2019; pp. 665-671.

21. Krejci, T.; Navratil, J.; Martinat, S.; Picha, K.; Klusacek, P.; Osman, R.; Skrabal, J. Past, present and future prospects for pre-1989 agricultural premises: The Vysocina Region. In Proceedings of the 23rd International Colloquium on Regional Sciences Conference Proceedings, Brno, Czech Republic, 17-19 June 2020; pp. 498-504.

22. Klusacek, P.; Martinat, S.; Krejci, T.; Bartke, S. Re-development of a former military training area-The case of Brdy told from a local actors' perspective. Land Use Policy 2019, 82, 147-157. [CrossRef]

23. Martinat, S.; Dvorak, P.; Frantal, B.; Klusacek, P.; Kunc, J.; Navratil, J.; Osman, R.; Tureckova, K.; Reed, M. Sustainable urban development in a city affected by heavy industry and mining? Case study of brownfields in Karvina, Czech Republic. J. Clean. Prod. 2016, 118, 78-87. [CrossRef]

24. Kunc, J.; Martinat, S.; Tonev, P.; Frantal, B. Destiny of urban brownfields: Spatial patterns and perceived censequences of post-socialistic deindustrialization. Transylv. Rev. Adm. Sci. 2014, 10, 109-128.

25. Rizzo, E.; Pesce, M.; Pizzol, L.; Alexandrescu, F.M.; Giubilato, E.; Critto, A.; Marcomini, A.; Bartke, S. Brownfield regeneration in Europe: Identifying stakeholder perceptions, concerns, attitudes and information needs. Land Use Policy 2015, 48, 437-453. [CrossRef]

26. Klusacek, P.; Konecny, O.; Zgodova, A.; Navratil, J. Application of the smart city concept in process of urban recycling - Case study of Špitálka in Brno, Czech Republic. Deturope-Cent. Eur. J. Reg. Dev. Tour. 2020, 12, 22-40.

27. CzechInvest. Národní Strategie Regenerací Brownfieldi̊; Ministerstvo průmyslu a obchodu: Praha, Czech Republic, 2008; Available online: http://www.cityinvestczech.cz/data/files/strategie-regenerace-vlada-1079.pdf (accessed on 3 August 2019).

28. Kittel, M.; Moller, H. The Benes decrees and the expulsion of the ethnic Germans seen from a European perspective. Vierteljahrsh. Fur Zeitgesch. 2006, 54. [CrossRef]

29. Kubes, J.; Kraft, S. South Bohemian Peripheral Areas and Their Social-Population Stability. Sociol. Cas.-Czech Sociol. Rev. 2011, 47, 805-829. [CrossRef]

30. Halamska, M. Changing property structures in Central European agriculture in the process of decollectivisation: The social aspects of appropriation. East. Eur. Countrys. 2008, 14, 7-25.

31. Lindbloom, J. A far-reaching shift in argumentation: Parliamentary debates on (post-)socialist agricultural cooperatives in the 1990s. East. Eur. Ctry. 2012, 18, 85-110. [CrossRef]

32. Pavlicova, M. Folk Culture at Free Disposal: Some Thoughts on its Protection and Use. In Od Folk K World Music: Cesty Za Vizí, 1st ed.; Přibylová, I., Uhlíková, L., Eds.; Městské kulturní středisko: Náměšt’ nad Ovlavou, Czechia, 2011; pp. 28-38.

33. Bezemer, D.J. Limitations on De-collectivisationin Central European Agriculture; Tinbergen Institute: Amsterdam, The Netherlands, 2000; p. 29.

34. Hlavsa, T.; Hruska, M.; Turkova, E. The impact of investment support from the Rural Development Programme of the Czech Republic for 2007-2013 on the economic efficiency of farms A comparison of the performance of farms within and outside Less Favoured Areas. Stud. Agric. Econ. 2017, 119, 11-17. [CrossRef]

35. ÚZEI. České Zemědělstvi Šest Let Po Vstupu Do Evropské Unie; Ústav Zemědělské Ekonomiky a Informací: Praha, Czech Republic, 2010.

36. Bezemer, D.J.; Stanikunas, D.; Zemeckis, R. Decline of corporate enterprises in t ransitional agriculture: Evidence from Lithuania. Comp. Econ. Stud. 2006, 48, 156-182. [CrossRef]

37. Martinat, S.; Navratil, J.; Trojan, J.; Frantal, B.; Klusacek, P.; Pasqualetti, M.J. Interpreting regional and local diversities of the social acceptance of agricultural AD plants in the rural space of the Moravian-Silesian Region (Czech Republic). Rend. Lincei-Sci. Fis. E Nat. 2017, 28, 535-548. [CrossRef] 
38. Frantal, B.; Kunc, J.; Novakova, E.; Klusacek, P.; Martinat, S.; Osman, R. Location matters! Exploring brownfields regeneration in a spatial context (A case study of the South Moravian Region, Czech Republic). Morav. Geogr. Rep. 2013, 21, 5-19. [CrossRef]

39. Frantal, B.; Greer-Wootten, B.; Klusacek, P.; Krejci, T.; Kunc, J.; Martinat, S. Exploring spatial patterns of urban brownfields regeneration: The case of Brno, Czech Republic. Cities 2015, 44, 9-18. [CrossRef]

40. Osman, R.; Frantal, B.; Klusacek, P.; Kunc, J.; Martinat, S. Factors affecting brownfield regeneration in post-socialist space: The case of the Czech Republic. Land Use Policy 2015, 48, 309-316. [CrossRef]

41. Krejci, T.; Dostal, I.; Havlicek, M.; Martinat, S. Exploring the hidden potential of sugar beet industry brownfields (case study of the Czech Republic). Transp. Res. Part D-Transp. Environ. 2016, 46, 284-297. [CrossRef]

42. Jancak, V.; Gotz, A. Územní Diferenciace Českého Zemědělství a Její Vývoj; Univerzita Karlova: Praha, Czech Republic, 1997; p. 81.

43. Navratil, J.; Picha, K.; Martinat, S.; Nathanail, P.C.; Tureckova, K.; Holesinska, A. Resident's preferences for urban brownfield revitalization: Insights from two Czech cities. Land Use Policy 2018, 76, 224-234. [CrossRef]

44. Kral, M. Spatial Difference of Multifunctional Agriculture in South Moravia Region. Geogr. Inf. 2014, 18 Pt 1, $115-125$. [CrossRef]

45. Svobodova, I.; Veznik, A.; Kral, M. Viticulture in the Czech republic: Some spatio-temporal trends. Morav. Geogr. Rep. 2014, 22, 2-14. [CrossRef]

46. Havlicek, M.; Svoboda, J.; Dostal, I. Development of sugar industry in Hodonin district and its effect on land-use changes and transport infrastructure. Listy Cukrov. A Reparske 2013, 129, 312-316.

47. Office, C.S. Agriculture. Available online: https://www.czso.cz/csu/czso/zemedelstvi_zem (accessed on 11 October 2020).

48. Martinat, S.; Navratil, J.; Dvorak, P.; Van der Horst, D.; Klusacek, P.; Kunc, J.; Frantal, B. Where AD plants wildly grow: The spatio-temporal diffusion of agricultural biogas production in the Czech Republic. Renew. Energy 2016, 95, 85-97. [CrossRef]

49. Perlin, R.; Kucerova, S.; Kucera, Z. A Typology of Rural Space in Czechia according to its Potential for Development. Geografie 2010, 115, 161-187. [CrossRef]

50. Navratilova, J.; Havlicek, M.; Navratil, J.; Frazier, R.J. Land cover changes on temperate organic substrates over last 150years: Evidence from the Czech Republic. Biologia 2019, 74, 361-373. [CrossRef]

51. Muchova, Z.; Tarnikova, M. Land cover change and its influence on the assessement of the ecological stability. Appl. Ecol. Environ. Res. 2018, 16, 2169-2182. [CrossRef]

52. Quinn, G.P.; Keough, M.J. Experimental Design and Data Analysis for Biologists; Cambridge University Press: Cambridge, UK, 2002.

53. Robinson, G.M. Methods and Techniques in Human Geography; J. Wiley: New York, NY, USA, 1998; 556p.

54. Leps, J.; Smilauer, P. Multivariate Analysis of Ecological Data Using CANOCO; Cambridge University Press: Cambridge, UK, 2003; p. 269.

55. ter Braak, C.J.F.; Smilauer, P. Canoco Reference Manual and Users Guide: Software for Ordination (Version 5.0); Microcomputer Power: Ithaca, NY, USA, 2012; p. 496.

56. Good, P. Permutation Tests: A Practical Guide to Resampling Methods for Testing Hypotheses; Springer: New York, NY, USA, 1995; p. 226.

57. Martinat, S.; Navratil, J.; Picha, K.; Tureckova, K.; Klusacek, P. Brownfield regeneration from the perspective of residents: Place circumstances versus character of respondents. Deturope-Cent. Eur. J. Reg. Dev. Tour. 2017, 9, 71-92.

58. Smith, G.D.; Ebrahim, S. Data dredging, bias, or confounding - They can all get you into the BMJ and the Friday papers. Br. Med. J. 2002, 325, 1437-1438. [CrossRef]

59. Rhodes, C.J. The imperative for regenerative agriculture. Sci. Prog. 2017, 100, 80-129. [CrossRef]

60. Banski, J. The consequences of changes of ownership for agricultural land use in Central European countries following the collapse of the Eastern Bloc. Land Use Policy 2017, 66, 120-130. [CrossRef]

61. Biolek, J.; Andrasko, I.; Maly, J.; Zrustova, P. Interrelated aspects of residential suburbanization and collective quality of life: A case study in Czech suburbs. Acta Geogr. Slov.-Geogr. Zb. 2017, 57, 66-75. [CrossRef]

62. Stastna, M.; Vaishar, A.; Vavrouchova, H.; Masicek, T.; Perinkova, V. Values of a suburban landscape: Case study of Podoli u Brna (Moravia), The Czech Republic. Sustain. Cities Soc. 2018, 40, 383-393. [CrossRef] 
63. Simon, M. Exploring Counterurbanisation in a Post-Socialist Context: Case of the Czech Republic. Sociol. Rural. 2014, 54, 117-142. [CrossRef]

64. Kubes, J. Analysis of regulation of residential suburbanisation in hinterland of post-socialist 'one hundred thousands' city of Ceske Budejovice. Bull. Geogr.-Socio-Econ. Ser. 2015, 27, 109-131. [CrossRef]

65. Simon, M.; Bernard, J. Rural Idyll Without Rural Sociology? Changing Features, Functions and Research of the Czech Countryside. East. Eur. Ctry. 2016, 22, 53-68. [CrossRef]

66. Popjakova, D.; Blazek, M. Verification of counterurbanisation processes: Example of the Ceske Budejovice region. Bull. Geogr.-Socio-Econ. Ser. 2015, 27, 153-169. [CrossRef]

67. Limasset, E.; Pizzol, L.; Merly, C.; Gatchett, A.M.; Le Guern, C.; Martinat, S.; Klusacek, P.; Bartke, S. Points of attention in designing tools for regional brownfield prioritization. Sci. Total Environ. 2018, 622, 997-1008. [CrossRef] [PubMed]

68. Norris, M.; Gkartzios, M.; Coates, D. Property-Led Urban, Town and Rural Regeneration in Ireland: Positive and Perverse Outcomes in Different Spatial and Socio-Economic Contexts. Eur. Plan. Stud. 2014, 22, 1841-1861. [CrossRef]

69. Veznik, A.; Konecny, O. Agriculture of the Czech Republic after accession to the EU: Regional differentiation. Morav. Geogr. Rep. 2011, 19, 50-62.

70. Stefunkova, D.; Hanusin, J. Viticultural landscapes: Localised transformations over the past 150 years through an analysis of three case studies in Slovakia. Morav. Geogr. Rep. 2019, 27, 155-168. [CrossRef]

Publisher's Note: MDPI stays neutral with regard to jurisdictional claims in published maps and institutional affiliations.

(C) 2020 by the authors. Licensee MDPI, Basel, Switzerland. This article is an open access article distributed under the terms and conditions of the Creative Commons Attribution (CC BY) license (http://creativecommons.org/licenses/by/4.0/). 